\title{
KONTRAK STANDAR DALAM PERKEMBANGAN HUKUM PEMBANGUNAN EKONOMI DARI PERSPEKTIF TEORI UTILITARIANISME
}

\author{
Dewa Ayu Putri Sukadana, Program Studi Magister Ilmu Hukum, Fakultas \\ Hukum Universitas Udayana, e-mail: dewaayu630@gmail.com \\ Dewa Gde Rudy, Fakultas Hukum Universitas Udayana, \\ e-mail: dewarudy1959@gmail.com
}

doi: $\underline{\text { https://doi.org/10.24843/KS.2020.v09.i01.p04 }}$

\begin{abstract}
ABSTRAK
Tujuan penulisan ini yaitu untuk mengkaji lebih lanjut mengenai penerapan dan berlakunya kontrak standar dari perspektif teori utilitarianisme. Penelitian ini menggunakan penelitian hukum normatif, yang berdasarkan dari sisi normatif yang menemukan kebenaran dalam logika keilmuan hukum. Sehingga penelitian hukum normatif merupakan penemuan aturan atau norma hukum yang tercantum dalam peraturan perundang-undangan, perjanjian, putusan pengadilan, serta pendapat para ahli hukum. Jenis pendekatan yang digunakan yaitu pendekatan perundang-undangan dan pendekatan analisis konsep hukum. Hasil pembahasannya yaitu penerapan kontrak standar dalam perkembangan hukum pembangunan ekonomi yaitu apabila konsumen telah mencantumkan tanda tangan atas kontrak standar yang telah disodorkan pelaku usaha kepada konsumen, maka hal tersebut berarti konsumen secara tidak langsung telah menyetujuinya. Dilihat dari perspektif Utilitarianisme maka Ketika Kontrak standar atau Klausula Baku memberikan manfaat bagi para pihak terutama bagi perkembangan hukum ekonomi terutama dalam bidang bisnis maka hal tersebut sesuai dengan aliran Utilitarianisme.
\end{abstract}

Kata Kunci: Standar Kontrak, Hukum Ekonomi, Utilitarianisme

\begin{abstract}
The purpose of this paper is to examine further the application and enforcement of the standard contract from the perspective of utilitarianism theory. This study uses normative legal research, which is based on the normative side that finds the truth in the scientific logic of law. So that normative legal research is the discovery of legal rules or norms contained in statutory regulations, agreements, court decisions, and opinions of legal experts. The type approach used is the Statute Approach and Analytical Conseptual Approach. The result of the discussion is the application of standard contracts in the development of economic development law, namely if the consumer has signed a standard contract that has been offered by the business actor to the consumer, then this means that the consumer has indirectly approved it. Seen from the perspective of Utilitarianism, when the standard Contract or Standard Clause provides benefits to the parties, especially for the development of economic law, especially in the business field, it is in accordance with the flow of Utilitarianism.
\end{abstract}

Key Words: Contract Standards, Economic Law, Utilitarianism.

\section{Pendahuluan}

\subsection{Latar Belakang Masalah}

Di Indonesia mempunyai tujuan kemerdekaan yaitu salah satunya untuk memajukan kesejahteraan umum yang sebagaimana dinyatakan dalam UndangUndang Dasar 1945 yang tercantum dalam pasal 33 ayat 4 yang berbunyi:

"Perekonomian nasional yang diselenggarakan berdasarkan atas demokrasi ekonomi dengan melalui prinsip kebersamaan, efisiensi, berkeadilan, 
berkelanjutan, berwawasan lingkungan, kemandirian serta dengan menjaga keseimbangan kemajuan dan kesatuan ekonomi nasional".

Jadi seperti yang telah dirumuskan dalam rumusan yang telah dipaparkan dalam pasal tersebut, Negara Indonesia adalah negara yang memiliki salah satu tujuan kemerdekaan yaitu untuk menciptakan kemakmuran, keadilan social secara seimbang dalam memakmurkan kehidupan rakyatnya. Sehingga negara Indonesia dapat memberikan keadilan yang berkeseimbangan dalam peningkatan perekonomian dalam kehidupan warga negaranya.

Di dalam Pancasila sila kelima selanjutnya ditegaskan dalam tujuan negara yang merdeka yaitu keadilan social bagi seluruh rakyat Indonesia yang merupakan salah satu dasar pandangan hidup bangsa negara indonesia. Negara Indonesia dalam landasan filosofis merupakan negara hukum yang modern, dimana negara kesejahteraan atau bahasa lainnya walfare state. Dalam mewujudkan dalam mencapai keadilan sosial apabila mewujudkan tugas dalam memajukan kesejahteraan warganya. Adapun tugas yang seharusnya dilakukan yaitu diantaranya bagaimana mengatur dan mengembangkan negara di bidang hukum dan ekonomi.

Dalam kehidupan masyarakat ekonomi merupakan hal yang tidak dapat disingkirkan. Ekonomi seiring waktu akan mengalami peningkatan dan perubahan yang drastis secara terus menerus dalam kehidupan manusia dengan perkembangan zaman. Pada perekonomian perubahan yang secara umum yang biasa terjadi Yaitu inflasi, meningkatnya pengangguran, kesempatan kerja, hasil produksi dan lain-lain yang dialami suatu negara. Apabila negara memiliki permasalahan ekonomi layaknya dapat ditangani secara cepat serta tepat. Agar menimbulkan keadaan yang stabil karena hal tersebut dapat mempengaruhi kesejahteraan masyarakat setempat.

Dalam hukum ekonomi perkembangan perekonomian global membawa dampak terhadap perkembangan hukum. Dalam zaman globalisasi pada negara berkembang yang dapat menyebabkan perubahan pada aturan hukum suatu negara mengenai investasi, perdagangan, jasa-jasa serta bidang ekonomi lainnya yang mendekati negara maju seperti yang disebutkan oleh Erman Radjagukguk. ${ }^{1}$ Pada dasarnya dalam konsep pertumbuhan ekonomi mengutip konsep pertumbuhan ekonomi yang dinyatakan dan telah diterapkan oleh Max Weber. Max Weber menyatakan bahwa peranan hukum dalam pembangunan pertumbuhan ekonomi setidaknya harus dapat menciptakan lima kondisi, yakni Stability, Predictibality, Fairness, Education, serta The Special Development Abilities Of Lawyers. ${ }^{2}$

Oleh karena hal tersebut dibutuhkan banyak aturan yang mengatur bagaimana agar masyarakat dapat melakukan aktivitas secara tentram, damai, serta tidak adanya saling kericuhan atau saling menghancurkan sehingga dalam memiliki kesempatan dalam mengembangkan ilmu pengetahuannya tidak terhambat diakibatkan hal tersebut. Perlunya peranan hukum yang efektif yang bertujuan untuk melindungi, menjaga, serta menyeimbangkan kehidupan ekonomi masyarakat. Sehingga dapat

${ }^{1}$ Radjagukguk, Erman, Peranan Hukum Dalam Pembangunan Pada Era Globalisasi, Jurnal Magister Hukum 6, No. 2 (2018): 114.

2 Fuad, Fokky. "Hukum, Demokrasi dan Pembangunan Ekonomi." Lex Jurnalica 5, no. 1 (2007): 17959 . 
menimbulkan dinamika perekonomian yang terarah untuk tercapainya kesejahteraan dan kemajuan untuk masyarakat. ${ }^{3}$

Dalam bidang hukum perjanjian merupakan salah satu bidang hukum yang perlu diperhatikan lebih untuk diatur maupun dikembangkan. Oleh sebab itu wujud dari sebagian besar kekayaan makhluk hidup yaitu terdapat pada perjanjian atau kontrak. 4

Dalam harta benda seseorang yang paling diperhatikan adalah keuntungan yang diperjanjikan oleh orang lain. Dalam sebuah perjanjian dapat melahirkan akibat hukum yaitu berupa hak dan kewajiban dari masing-masing pihak. Suatu hal yang disebut hak bagi salah satu pihak dalam suatu kontrak juga akan merupakan kewajiban bagi pihak lainnya. Di Indonesia ketentuan-ketentuan Buku III KUHPerdata tentang Perikatan merupakan ketentuan hukum perjanjian yang banyak digunakan.

Asas yang dapat melandasi hukum perjanjian yang merupakan asas utama yaitu asas kebebasan berkontrak. Di dalam suatu kontrak sebagai hubungan pribadi yang berkelanjutan, tidak berbeda dengan yang lainnya, dimana pada umumnya suatu kontrak diatur oleh seperangkat norma-norma atau aturan-aturan hukum yang berlaku. Aturan tersebut dapat mewajibkan, menyuruh, ataupun melarang perilaku seseorang yang menyimpang dari aturan yang telah ditentukan. Perilaku yang biasa dilakukan seringkali digantungkan pada kondisi-kondisi tertentu saja. Perilaku yang dianggap baik akan dapat menimbulkan hak untuk memperoleh insentif sedangkan perilaku yang melanggar dapat diancam dan dikenakan sanksi. Namun pada umumnya berbeda dengan transaksi-transaksi non kontraktual dimana sebagian besar dari transaksi dan dalam suatu perikatan akibat perjanjian yang telah diatur secara tertulis dalam kontrak-kontrak. Jadi dengan kata lain, dalam sebuah kontrak akan membentuk suatu etentias privat antara pihak pembuatnya dimana kedua belah pihak memiliki hak yuridis untuk menuntut pelaksanaan serta kepatuhan terhadap pembatasan suatu kontrak yang telah disepakati secara sukarela oleh pihak lain.

Secara tegas maupun secara tersirat piranti tertulis dalam perjanjian atau persetujuan, yang dapat dilakukan dan ditegakkan menurut hukum disebut sebagai kontrak. Di dalam suatu kontrak, diperuntukkan menimbulkan janji timbal balik antara para pihak seperti janji dibalas dengan jani. Pada kontrak yang telah dibuat menurut hukum, diwajibkan untuk memenuhi syarat-syarat sahnya suatu kontrak seperti yang tercantum dalam KUHPerdaya sehingga dapat dilaksanakan dan dapat ditegakkan.

Dalam prakontrak, asas konsensualisme dan asas kebebasan berkontrak. Asas konsesualisme, dalam kontrak diungkapkan telah lahir apabila adanya kata sepakat atau kesesuaian kehendak kedua belah pihak yang akan membuat kontrak. ${ }^{5}$ Sehingga dengan adanya kesepakatan atau janji timbal balik dari berbagai pihak untuk saling berprestasi, muncullah kesepakatan untuk saling mengikatkan diri satu sama lain. Adapun sifat yang terpenting dari sebuah kontrak seperti yang ditambahkan oleh Lord Steyn adalah bertemunya kesepakatan para pihak dan saling mengikatkan diri yang berarti salah satu pihak melakukan tawar menawar dan pihak lainnya menerimanya.

${ }^{3}$ Zaini, Zulfi Diane. "Perspektif Hukum Sebagai Landasan Pembangunan Ekonomi Di Indonesia (Sebuah Pendekatan Filsafat)." Jurnal Hukum 28, no. 2 (2020): 929-957.

${ }^{4}$ Jamilah, Lina. "Asas Kebebasan Berkontrak Dalam Perjanjian Standar Baku." Syiar Hukum 14, No. 1 (2012): 26-36.

5 Khairandy, Ridwan. "Landasan Filosofis kekuatan mengikatnya kontrak." Jurnal Hukum IUS QUIA IUSTUM 18 (2011): 36-55. 
Terdapat kelemahan yang dimiliki dalam perumusan suatu kontrak yaitu dari segi pelaku usaha dalam membuat suatu perjanjian. Sehingga dalam hal pelaku usaha, dalam membuat suatu perjanjian yang seolah-olah hanya satu pihak yang menentukan sedangkan pihak lainnya hanya menerimanya, yang seharusnya dalam kontrak atau perjanjian para pihak saling mengikatkan diri satu sama lain.

Sehingga disimpulkan oleh para ahli dengan menyempurnakan rumusan yang telah dipaparkan diatas, dalam suatu perjanjian dimana perbuatan hukum yang dilakukan oleh dua atau lebih subyek hukum (orang) yang sepakat untuk saling mengikatkan diri satu sama lain. Jadi perumusan tersebut hanya perbuatan hukumlah yang dapat dikatakan perjanjian haruslah saling mengikatkan diri, oleh karenanya pada dasarnya suatu perjanjian dapat dikatakan kedua belah pihak yang telah berjanji untuk saling mengikatkan diri.

Sejak lama yang menjadi bahasan oleh para sarjana hukum di Indonesia yaitu perjanjian baku atau yang sering disebut Kontrak standar. Dalam berbagai literatur, para sarjana hukum sudah membuka diskursus dan memberikan pengertian mengenai klausula baku. Fakta di masyarakat sangat jarang yang ingin membuat suatu kontrak para pihaknya mempunyai posisi yang seimbang. Yang dimana dalam kontrak tersebut pihak yang satu memiliki posisi yang lebih kuat dalam menentukan isi kontrak. Kontrak yang paling sering menonjolkan hanya satu pihak saja yang lebih kuat adalah standard voorwarden dalam bahasa Belanda atau yang sering disebut juga standard contract dalam bahasa inggris.

Dalam perkembangan, semakin meluasnya penggunaan kontrak standar atau perjanjian baku, karena praktis, efisien serta efektif karena cepat sehingga menghemat biaya, tenaga dan waktu. Perjanjian yang dekat dan sering terjadi dalam kehidupan sehari-hari digunakan perjanjian yaitu perjanjian baku, misalnya, perjanjian parkir, asuransi, jual beli rumah, kartu kredit, kredit perbankan, pengiriman barang, sewamenyewa, dan lain sebagainya. Perjanjian merupakan aspek yang penting dalam kegiatan transaksi bisnis yang dilakukan antar individu dalam sebuah negara satu dengan lainnya maupun hubungan perusahaan yang bersifat lintas batar negara. Perjanjian tersebut timbul karena adanya kesepakatan para pihak. Sehingga dalam perjanjian minimal dua atau lebih yang sepakat untuk mengikatkan dirinya.

Dapat dipastikan bahwa dengan adanya kata sepakat dalam suatu kontrak tersebut yang didasarkan pada kebebasan berkontrak. Kebebasan para pihak tersebut dalam artian, dalam mengadakan suatu perjanjian atau kontrak standar, salah satu pihak diberikan kebebasan untuk menentukan dengan siapa mengadakan perjanjian dan bebas dalam hal menentukan isi dan bentuk kontrak tersebut sehingga itulah yang disebut dengan kebebasan berkontrak. Pada kebebasan berkontrak adapun doktrin mendasar yang sudah melekat yaitu kontrak yang dilahirkan ex nibilo yang berarti kontrak yang perwujudannya kebebasan para pihak dalam membuat suatu kontrak. ${ }^{6}$

Pemberlakuan standar kontrak terdapat asas yang utama yang berlaku pada hukum perjanjian yang tidak terlepas dari masyarakat adalah asas konsesualisme. Dimana asas konsesualisme berarti asas yang menonjolkan pada aspek pencapaian kata sepakat para pihak satu dan pihak lainnya dalam standar kontrak dan asas pacta sun servanda yang selalu mengutamakan kepada kepastian hukum pihak satu dengan

${ }^{6}$ Muskibah, Muskibah, and Lili Naili Hidayah. "PENERAPAN PRINSIP KEBEBASAN BERKONTRAK DALAM KONTRAK STANDAR PENGADAAN BARANG DAN JASA PEMERINTAH DI INDONESIA." Refleksi Hukum: Jurnal Ilmu Hukum 4, no. 2 (2020): 175-194. 
pihak lainnya pada perjanjian menjadi perikatan yang mencerminkan seperti terjadinya penandatanganan para pihak dalam standar kontrak tersebut.

Dalam KUH Perdata pada pasal 1338 ayat (1) ini diatur mengenai asas kebebasan berkontrak yang berbunyi:

"Perjanjian yang telah dibuat secara sah berlakunya sebagai Undang-Undang bagi mereka yang telah membuatnya".

Dalam asas kebebasan berkontrak yang menekankan pada kebebasan dalam membuat perjanjian atau tidaknya, melakukan perjanjian terhadap siapapun, telah menentukan isi suatu perjanjian, pelaksanaan dan persyaratan, serta menentukan bagaimana bentuk dari perjanjian yang telah dibuat apakah tertulis maupun tidak tertulis.

Dalam Undang-Undang Perlindungan Konsumen yang kaitannya dengan hal di atas, yang memaparkan pengertian mengenai klausula baku yang tercantum pada UU Perlindungan Konsumen pasal 1 angka 10, yang berbunyi:

"Klausula baku adalah aturan-aturan atau ketentuan dan syarat-syarat yang telah dipersiapkan dan ditetapkan terlebih dahulu oleh pelaku usaha secara sepihak, yang dituangkan dalam dokumen dan atau perjanjian yang mengikat para pihak dan wajib dipenuhi oleh konsumen."

KUH Perdata dalam pasal 1313 dalam menjelaskan mengenai pengertian perjanjian, yang berbunyi, suatu perbuatan antara satu orang atau bahkan lebih untuk saling mengikatkan satu sama lain. Menurut Soebekti dalam menjelaskan mengenai pengertian dari perjanjian yaitu suatu peristiwa dimana para pihak telah berjanji untuk melakukan sesuatu hal yang dituangkan dalam sebuah perjanjian. Sehingga dapat disimpulkan dari defenisi di atas yaitu perjanjian merupakan suatu pernyataan yang telah dibuat oleh seseorang yang cakap hukum menurut Undang-Undang yang dimana para pihak telah sepakat untuk saling mengikatkan dirinya masing-masing terhadap suatu hal tertentu. Dengan demikian dari sebuah perjanjian yang telah disepakati bersama adapun unsur-unsurnya yaitu orang yang mengadakan perjanjian, terdapat kesepakatan berupa hak dan kewajiban, serta objek yang diperjanjikan. ${ }^{7}$

Kontrak standar merupakan sebuah istilah yang biasanya digunakan dalam hal perjanjian yang seluruh kalusula-klausulanya telah dibakukan oleh penggunanya. Sehingga pihak yang lainnya tidak memiliki kesempatan untuk bernegosiasi mengenai perubahan yang terjadi. Kontrak standar pada hakekatnya yang telah tercetak disodorkan sehingga pihak lain tidak memiliki kesempatan untuk melakukan negosiasi atau menawar, yang ada adalah pilihan mengambil kontrak tersebut atau meninggalkannya (take or leave it). Hondius juga mengemukakan dalam hal kontrak yang belum dibakukan terkait dengan seputaran objek yang ditransaksiskan dan besaran biaya yang ditanggung. Semakin pesatnya dunia bisnis sekarang ini, diperlukannya kontrak standar yang untuk mengifisiensikan biaya, tenaga, dan waktu dalam perjalanan bisnis. Contohnya perjanjian yang sering ditemui sebagai kontrak standar yaitu kredit bank, jual beli, tiket pesawat, tiket parkir, dan lain sebagainya.

Secara khusus yang merupakan lex special dalam Undang-Undang Perlindungan Konsumen yang tercantum pada pasal 1337 dan pasal 1339 yang terdpat

${ }^{7}$ Hernoko, Agus Yudha, Hukum Perjanjian Asas Proposional Dalam Kontrak Komersial, (Jakarta, Kencana, 2010), 35-36. 
pada KUHPerdata yang telah mengatur ketentuan-ketentuan penerapan isi dalam Kontrak Standar yaitu sebagai berikut:

a. tidak diperbolehkan dalam melakukan pengalihan tanggung jawab pelaku usaha;

b. barang yang sudah dibeli konsumen tidak dapat serahkan kembali dan pelau usaha berhak menolak barang tersebut;

c. apabila konsumen menyerahkan kembali uang yang telah dibayarkan atas barang yang dibeli, pelaku usaha berhak menolak hal tersebut;

d. pemberian kuasa yang dilakukan oleh konsumen terhadap pelaku usaha dalam melakukan segala perbuatan sepihak yang berkaitan dengan barang/jasa yang dibeli konsumen secara angsuran;

e. apabila terjadi hilangnya kegunaan barang ataupun jasa yang dibeli, konsumen berhak mempunyai pembuktian;

f. mengurangi manfaat harta kekayaan dan mengurangi manfaat jasa konsumen yang menjadi objek jual beli jasa;

g. dalam aturan yang telah ditentukan selama masa pemanfaatan barang dan jasa, konsumen wajib mematuhinya;

h. konsumen berhak menyatakan dalam hal memberi kuasa terhadap pelaku usaha untuk pembebasan hak tanggungan, hak gadai, hak jaminan secara angsuran terhadap barang yang dibeli;

i. tidak diperbolehkan mencantumkan klausula baku seperti yang tercantum dalam Undang-Undang Perlindungan Konsumen pasal 18 ayat 1.

Tentunya akan lebih mudah apabila mengacu pada ketentuan di atas dalam mendefinisikan apakah kontrak standar yang disodorkan oleh pelaku usaha berpengaruh dapat merugikan konsumen atau dapat bermanfaat bagi masyarakat (teori utilitarianisme).

Teori utilitarinisme merupakan pandangan yang dapat dinyatakan sebagai tindakan dan kebijakan yang dievaluasi berdasarkan manfaat dan biaya yang ditanggung oleh masyarakat. Dalam prinsip moral dinyatakan bahwa sesuatu yang dianggap benar apabila mampu menekan biaya sosial dan menimbulkan manfaat sosial terhadap penggunanya. Dalam keadaannya bagaimanapun, sesuatu atau tindakan yang dianggap benar merupakan tindakan yang dapat memberikan manfaat yang paling besar untuk masyarakat.

Pendiri utilitarianisme yaitu Jeremy Bentham pada tahun 1748-1832. Melihat dari berbagai kebijakan yang telah ditetapkan Jeremy Bentham berusaha mencari dasar objektif dengan membandingkan manfaat serta konsekuensi-konsekuensi dalam membuat suatu keputusan yang dapat memberikan norma yang diterima oleh masyarakat dalam hal menetapkan kebijakan dan peraturan-peraturan sosial. Menurut Jeremy Bentham dari sudut pandang etis, tindakan yang benar dan tepat yaitu tindakan yang dapat mempengaruhi utilitas yang besar untuk public.

Terdapat tiga kriteria dari prinsip utilitarianisme yaitu: ${ }^{8}$

8 Junaidy, Abdul Basith. "MEMAHAMI MASLAHAH MELALUI FILSAFAT MANFAAT: UTILITARIANISME." Penelitian Individu (2013),12-13 
1. Kriteria yang pertama yaitu kriteria yang dapat dijadikan dasar objektif dalam hal menilai perilaku atau perbuatan yang menimbulkan manfaat atau utilitas. Sehingga sebelum menentukan perbuatan atau kebijakan yang mana yang menghasilkan manfaat dan perbuatan mana yang mendatangkan kerugian.

2. Kriteria kedua yaitu manfaat terbanyak. Dalam setiap alternative dalam penilaian segala perbuatan atau tindakan yang telah dilakukan baik secara moral apabila memberikan manfaat lebih banyak dibandingkan kerugian yang ditimbulkan oleh tindakan tersebut.

3. Kriteria ketiga yaitu untuk siapa manfaat terbanyak yang telah dilakukan. Dalam suatu perbuatan atau tindakan tepat dan benar secara moral apabila dapat menimbulkan manfaat terbesar terhadap sebanyak mungkin masyarakat tanpa mendatangkan kerugian.

Suatu doktrin moral mengatakan bahwa utilitarianisme merupakan tindakan yang seharusnya menghasilkan sebanyak mungkin kemanfaatan ( rasa bahagia dan nikmat ) bagi setiap orang yang terpengaruh akan perbuatan yang kita lakukan. Dengan demikian, teori utilitarianisme memiliki kriteria objektif yaitu manfaat terbesar untuk sebanyak mungkin masyarakat atau bahkan sebagian besar dari masyarakat itu sendiri. Dengan kata lain the greatest good for the greatest number, dari segi etis dalam suatu tindakan yang baik merupakan kebijakan atau tindakan yang memberi pengaruh terhadap sebagian besar masyarakat dan sebaliknya akan membawa kerugian yang sekecil mungkin bagi sedikit masyarakat.

Namun harus diingat bahwa teori utilitarianisme mengukur kebahagiaan dan kesenangan tidak hanya terdapat pada individu tetapi juga pada masyarakat. sehingga perlu dipertimbangkan apakah dampak dari suatu keputusan, tetapi yang perlu diukur bukan hanya rasa senang atau sakit dari pembuat keputusan melainkan semua orang yang mungkin terkena dalam keputusan tersebut. Individu seolah-olah menjadi penonton yang tidak memihak karena kebahagiaan yang menjadi standar bagi tindakan bukanlah kebahagiaan pribadi namun juga kebahagiaan semua pihak. Bagi para utilitarian pun tidak bisa menerima bahwa tujuan akhir menghalalkan cara atau sarana. Lagi pula tujuan dasar utilitarianisme adalah kebahagiaan bagi sebanyak mungkin orang (untuk kepentingan bersama). Sehingga penulis ingin mengangkat judul "Kontrak Standar Dalam Perkembangan Hukum Pembangunan Ekonomi Dari Perspektif Teori Utilitarianisme".

Artikel ilmiah ini dibuat dengan judul Kontrak Standar Dalam Perkembangan Hukum Pembangunan Ekonomi Dari Perspektif Teori Utilitarianisme berdasarkan keinginan untuk memahami konsep perlindungan hukum pembangunan ekonomi yang tepat dan sesuai dengan kondisi sosial masyarakat Indonesia khususnya terkait konsep penerapan kontrak standar dalam perkembangannya di Indonesia sesuai dengan KUHPerdata yang berlaku saat ini yang belum terdapat publikasi ilmiah yang sama atau memiliki persamaan pada prinsipnya dengan permasalahan yang dikaji pada artikel ilmiah ini baik dalam jurnal nasional maupun internasional.

\subsection{Rumusan Masalah}

Sesuai dengan latar belakang yang telah dipaparkan diatas, sehingga dapat dirumuskan permasalahan yaitu sebagai berikut:

1. Bagaimanakah penerapan kontrak standar dalam perkembangan hukum pembangunan ekonomi? 
2. Bagaimanakah berlakunya kontrak standar di Indonesia dari perspektif teori utilitariasnisme?

\subsection{Tujuan Penulisan}

Tujuan penelitian ini adalah untuk mengetahui penerapan pada kontrak standar dalam perkembangan hukum pembangunan ekonomi dan juga untuk mengetahui dan memahami berlakunya suatu kontrak standar di Indonesia dari perspektif utilitarianisme.

\section{Metode Penelitian}

Jenis penelitian yang digunakan yaitu penelitian hukum normatif. Penelitian hukum normatif yaitu penelitian yang menimbulkan kebenaran berdasarkan logika keilmuan hukum dalam segi normatifnya. Sehingga penelitian hukum normatif merupakan penelitian terhadap aturan-aturan atau norma-norma hukum yang tercantum dalam peraturan perundang-undangan, dalam perjanjian, dalam putusan pengadilan dan pendapat para ahli hukum. ${ }^{9}$ Jenis pendekatan yang digunakan yaitu melakukan pendekatan Undang-undang, dalam artian penelitian hukum yang dilakukan terkait dengan penelitian yang berkaitan dengan norma hukum tertulis. Norma hukum tertulis yang dimaksud yaitu Peraturan Perundang-Undangan serta mengacu pada penelitian tentang sistematika hukum dan menganalisis kumpulan aturan atau norma hukum yang terkumpul dalam peraturan-peraturan tertentu.

\section{Hasil dan Pembahasan}

\subsection{Penerapan Kontrak standar dalam Perkembangan Hukum Pembangunan Ekonomi}

Kontrak standar dikenal sejak pada jaman Yunani Kuno. Menurut Harvard Law a Review dalam laporannya pada tahun 1971 bahwa 99\% perjanjian dibuat di Amerika serikat yang berbentuk Kontrak Standar. Dalam dunia usaha ataupun dunia bisnis Kontrak Standar sangat berperan penting bagi perkembangan dalam aktivitas perdagangan barang dan/atau jasa.

Tidak dapat di pungkiri, apabila dipandang dari segi waktu, tenaga dan biaya dalam perjanjian seperti kontrak standar ini di sisi lain menimbulkan keuntungan dan dapat diminimalisir. Biasanya Kontrak Standar diterapkan oleh para pelaku usaha dalam transaksi bisnis maupun ekonomi yang hakikatnya untuk menawarkan kepada setiap konsumen berupa barang maupun jasa misalnya pada pelayanan jasa parkir, pemberian kredit, jual beli rumah dan berbagai transaksi bisnis lainnya.

Menurut Mariam Badrulzaman karakteristik dari kontrak baku atau kontrak standar, yaitu sebagai berikut: 10

1. isi kontrak yang dilakukan secara sepihak terhadap pihak yang memiliki posisi tawarnya (ekonominya) lebih kuat

2. dalam isi kontrak atau perjanjian, konsumen tidak ikut campur dalam menentukan isi tersebut;

3. dikarenakan debitur memiliki posisi yang rendah, debitur hanya dapat menerima perjanjian yang telah ditetapkan;

9 Ardana, I Nyoman, Kewenangan Pejabat Pembuat Akta Tanah Dalam Pembebanan Hak Tanggungan, Tesis Universitas Mahendradatta, Denpasar (2013), 23.

${ }^{10}$ Mariam Badrulzaman, Aneka Hukum Bisnis, (Bandung, PT Alumni, 2005), 18-19 
4. kontrak standar berbentuk tertulis; serta

5. kontrak standard yang telah dipersiapkan secara masal dan kolektif.

Kontrak standar dengan perkembangan ekonomi merupakan hal yang sangat erat kaitannya. Dalam sebuah perusahaan seringkali mempergunakan perjanjian yang dilakukan secara sepihak oleh pelaku usaha. Biasanya perjanjian tersebut dapat disebut dengan perjanjian baku atau standar kontrak. Sehingga dengan demikian, sedikit banyaknya dalam melakukan suatu aktivitas langsung yang berhubungan beberapa orang, pelaku usaha seringkali menggunakan kontrak standar untuk melakukan transaksi bisnisnya. Berdasarkan hal tersebut, diperlukan efisiensi dalam kegiatan berbisnis yang dapat menimbulkan perkembangan dalam penggunaan suatu perjanjian.

Dalam kontrak standar, esensinya memang terwujudnya sepakat antara pihak namun kontrak standar yang masih diragukan oleh konsumen yaitu dalam penentuan isi dalam kontrak yang dilakukan secara sepihak, sedangkan Asser Rutter mengatakan, dalam penentuan isi kontrak tidaklah perlu dipermasalahkan, karena setiap konsumen yang telah menandatangani kontrak yang telah disodorkan, harus dapat bertanggung jawab atas isi kontrak yang telah ditandatangani. Jika salah satu pihak dalam formulir standar kontrak telah mencantumkan tanda tangannya, tanda tangan tersebut telah menimbulkan rasa percaya bahwa salah satu pihak yang membubuhi tanda tangan telah mengetahui dan menyetujui seluruh isi dari formulir kontrak yang telah disodorkan.

Dengan demikian, seperti yang telah dijelaskan, untuk mengasumsikannya apakah kontrak standar dapat menimbulkan kerugian terhadap konsumen tidak hanya berpegangan terhadap kata sepakat, namun memerlukan perbandingan isi beserta pelaksanaan kontrak standar tersebut yang dimana termasuk sebagai penerapan dalam asas kebebasan berkontrak. Asas kebebasan berkontrak merupakan asas yang semua pihak memiliki kebebasan dalam menjalin hubungan saling terikat dengan pihak lainnya, termasuk bebas menentukan syaratnya, pelaksanaannya dan bentuk kontraknya. Dalam KUH Perdata pasal 1338 dinyatakan bahwa semua kontrak perjanjian yang telah dilakukan secara tidak sah berlaku sebagai Undang-Undang bagi mereka yang melakukannya. ${ }^{11}$

Dalam setiap level transaksi bisnis bentuk standar kontrak telah muncul. Sehingga dapat dikatakan munculnya kontrak standar merupakan akibat tidak langsung dari KUH Perdaya dalam pasal 1320 dan pasal 1338 yaitu asas kebebasan berkontrak. Awal munculnya dari transaksi bisnis yang berskala besar sampai dengan berskala kecil. Dalam suatu kontrak, untuk seimbangnya posisi tawar menawar dari para pihak dan adanya keadaan memaksa dari pihak lainnya, tidak adanya aturan yang substansial yang mampu untuk menyeimbangkan hal tersebut. Yang sering digunakan dalam kontrak standar dalam setiap perjanjian yang bersifat sepihak, yang umumnya disebut dengan bahasa disclaimer. Disclaimer tersebut bertujuan untuk melindungi pihak yang memberikan suatu jasa tertentu.

11 Hendrawati, Dewi. "Penerapan Asas Kebebasan Berkontrak dalam Pembuatan Perjanjian Baku (Studi Normatif pada Perjanjian Pembiayaan Konsumen)." Masalah-Masalah Hukum 40, no. 4 (2011): 411-418. 
Menurut Munir Fuadi terdapat prinsip-prinsip yang perlu diperhatikan dalam suatu Kontrak Standar secara khusus memiliki prinsip tambahan di luar perjanjian biasa yaitu: ${ }^{12}$

a. Kesepakatan kehendak kedua belah pihak.

Dalam sahnya suatu perikatan yaitu kesepakatan, akan selalu dijadikan sebuah penentuan sahnya atau tidak suatu Kontrak yang telah dibuat. Pasal $1320 \mathrm{KUH}$ Perdata sudah menjelaskan dapat dikatakan perjanjian yang dapat dikatakan sudah sah, apabila terjadinya kata sepakat antara kedua belah pihak. Meskipun, kontrak standard tersebut dibuat oleh salah satu pihak saja, unsur dari kata sepakat tersebut harus dapat dilengkapi dalam kontrak standard, kata sepakat yang dimaksud dengan ditandai tanda tangan kontrak atau dengan cara serah terima terhadap barang yang ditransasikan.

b. Asumsi resiko kedua belah pihak

Dengan adanya asumsi resiko dalam suatu kontrak tidaklah ada larangan. Sehingga dapat disimpulkan jika salah satu pihak telah sepakat menanggung risiko yang diterima. Apabila resiko tersebut telah terjadi, maka yang menyatakan telah sepakat haruslah siap untuk menanggung resiko tersebut.

c. Kewajiban membaca

Dalam prinsip kewajiban membaca ini yang dilakukan oleh konsumen, yang dianut oleh sistem Negara common law seperti di Amerika. Dalam disiplin ilmu hokum mengajarkan, bahwa setiap pihak harus membaca terlebih dahulu kontrak yang akan mereka tanda tangani sebelum mengatakan kata sepakat. Tanda tangan yang akan dibubuhkan dalam kontrak tersebut yaitu tanda kedua belah pihak sudah membaca sepenuhnya isi dari kontrak tersebut.

d. Kontrak mengikuti kebiasaan

Kontrak yang dapat dikatakan sebagai role yang dapat mengatur apa yang boleh dilakukan maupun tidak boleh dilakukan oleh kedua belah pihak, bukan semata-mata yang tidak tercantum dalam kontrak boleh dilakukan ataupun tidak. Sehingga terdapat prinsip kebiasaan yang dapat mengikat kedua belah pihak dalam suatu perjanjian.

Dalam kontrak standar, seringkali pelaku usaha dalam menentukan isi dari sebuah perjanjian dilakukan secara sepihak dan dituangkan dalam bentuk berupa formulir dengan yang jumlah yang banyak. Sehingga dapat dipergunakan kembali apabila akan melakukan penawaran terhadap konsumen.

Dikaji dalam sisi ekonomi, dalam menentukan isi dari suatu perjanjian secara sepihak memanglah baik untuk diterapkan karena pelaku usaha dan konsumen tidak memerlukan tawar menawar, telah jelas hal tersebut dapat menguntungkan dalam segi waktu, tenaga dan biaya yang dikeluarkan. Namun, akan dapat menimbulkan masalah apabila pelaku usaha sebagai pihak yang berperan penting dalam menentukan ini suatu perjanjian yang dilakukan dengan mencantumkan klausula-klausua baku yang dapat merugikan konsumen.

12 Munir Fuady, Dr SH. Doktrin-doktrin modern dalam corporate law \& eksistensinya dalam hukum Indonesia. Citra Aditya Bakti, (2014), 22-23 
Terdapat empat metode atau cara berlakunya syarat-syarat baku dalam suatu Kontrak Standar dalam penerapannya kontrak standar, yaitu sebagai berikut: ${ }^{13}$

a. Dalam penandatanganan perjanjian kontrak standard, dokumen perjanjian kontrak standard yang secara lengkap dan syarat-syarat kontrak standard. Ketika dalam membuat Kontrak Standar, kontrak standar tersebut disodorkan kepada konsumen untuk selanjutnya dibaca dan ditandatangani. Sehingga dengan ditandatanganinya kontrak tersebut, dapat dikatakan konsumen secara tidak langsung sepakat terhadap klausula-klausula yang tercantum dalam kontrak standar tersebut.

b. Dalam kontrak standar, syarat-syarat baku yang telah dicetak dalam dokumen perjanjian yang tidak ditandatangani oleh konsumen seperti suatu penerimaan, surat pesanan dan nota pembelian suatu barang. Syarat dalam kontrak tersebut dapat diberitahukan melalui dokumen perjanjian.

c. Penunjukan dalam formulir kontrak standar, dalam hal ini tidak mencantumkan mengenai syarat-syarat baku melainkan hanya mencantumkan kepada syarat-syarat baku contohnya perjanjian jual beli dalam dagang, ditunjuk sebagai suatu syarat penyerahan barang secara langsung sehingga syarat baku mengenai penyerahan barang tersebut berlaku dalam perjanjian.

d. Dalam kontrak standar, adanya pemberitahuan dalam papan pengumuman mengenai syarat baku, dapat dijadikan sebagai bagian dari isi suatu perjanjian yaitu dengan cara melalukan pemberitahuan melalui papan pengumuman. Sehingga dalam tersebut, papan pengumuman yang akan dipasang harus mudah dibaca jelas oleh konsumen, sebelum perjanjian dibuatkan.

Dapat disimpulkan, dari empat metode yang telah dipaparkan diatas, bahwa ketika konsumen telah sepakat melakukan penandatanganan atas kontrak standar yang disodorkan oleh pelaku usaha kepada konsumen, maka hal tersebut dapat dikatakan konsumen telah menyetujui (take it) klausul-klausul perjanjian yang tercantum dalam kontrak standar tersebut.

\subsection{Berlakunya Kontrak Standar di Indonesia dari Perspektif Teori Filsafat Utilitarianisme}

Seperti yang telah dijelaskan diatas Kontrak standar atau biasa disebut sebagai klausula baku yang penggunaanya praktis, efisien dan efektif karena menghemat biaya, tenaga dan waktu. Kontrak standar umumnya membuat salah satu pihak berkedudukan lebih kuat posisi kedudukannya maupun dalam hal ekonominya. Dengan demikian syarat-syarat yang telah dibuat sesuai dengan kehendak yang membuatnya, maka pihak yang posisinya lemah tidak mempunyai banyak pilihan selain memilih take it or leave it. ${ }^{14}$

Di dalam perkembangan hukum ekonomi, hukum bisnis terutama hukum kontrak, tentunya mengedepankan kesepakatan para pihak yang masing-masing telah

${ }_{13}$ Panggabean, R. M. "Keabsahan Perjanjian dengan Klausul Baku." Jurnal Hukum Ius Quia Iustum 17.4 (2010): 651-667.

${ }^{14}$ Syaifuddin, Muhammad, Hukum Kontrak (Bandung, Mandar Maju, 2012), 56- 57 
menganalisa posisi atau keunggulannya dalam suatu bisnis atau kegiatan ekonomi sehingga dapat memberikan manfaat yang baik bagi para pihak. ${ }^{15}$ Tercantum dalam pasal 1338 ayat (1) KUHPerdata dinyatakan, bahwa semua kontrak ataupun perjanjian yang telah dibuat secara sah berlaku sebagai Undang-Undang bagi mereka yang membuatnya.

Berlakunya suatu kontrak sebagai undang-undang dalam perkembangan hukum ekonomi tentunya akan mengedepankan keadilan, kepastian hukum dan kemanfaatan. Jika dikaji berlakunya kontrak standar atau klausula baku di Indonesia dari perspektif Aliran Utilitarianisme dapat dilihat dari manfaat adanya kontrak standar atau klasusula baku dalam kehidupan masyarakat, khususnya masyarakat ekonomi.

Untuk membahas lebih lanjut, haruslah mengetahui apa definisi teori utilitarianisme tersebut. Utilitarianisme merupakan teori yang menonjolkan manfaat atau kegunaan penilaian suatu perbuatan sebagai suatu prinsip moral yang paling umum yang terdapat paham dalam filsafat moral, untuk dapat menentukan suatu perbuatan yang baik, apabila dapat menimbulkan manfaat kepada masyarakat. ${ }^{16}$

Dari konsep yang telah dijelaskan tersebut, adapun istilah yang dikenal dengan Deontologi yang berasal dari bahasa Yunani, yaitu "deon" yang artinya kewajiban. Sehingga pengertian deontology merupakan teori etika yang dapat dinyatakan teori yang menjadi dasar baik buruknya suatu perilaku atau perbuatan merupakan suatu kewajiban bagi seseorang untuk melakukan kebaikan kepada sesame, sebagaimana keinginan dari diri sendiri untuk selalu bersikap dan berperilaku baik terhadap diri sendiri.

Pandangan utilitarianisme paham bisnis merupakan etis, jika dalam melakukan hal yang menyangkut mengenai bisnis yang dapat memberikan manfaat yang besar pada sebagian besar masyarakat. Sehingga, kegiatan atau kegiatan bisnis yang baik adalah bukan berarti memberikan kerugian melainkan memberikan kebijakan yang menimbulkan berbagai hal-hal yang baik dan memberikan manfaat tanpa menimbulkan kerugian bagi masyarakat. ${ }^{17}$ Teori utilitarianisme berasal dari bahasa Latin yaitu 'Utilitas', yang artinya kegunaan. Apabila dilihat dari segi kegunaan yang ditimbulkan, teori ini menilai baik atau tidaknya sesuatu tindakan. Para ahli Jerremy Bentham dan John Stuart Mill, mencetuskan teori ini pada abad ke-19 sebagai kritik dari dominasi hukum alam. Teori ini biasa disebut sebagai teori kebahagiaan terbesar (the greatest happiness theory) dan teori teleologis.

Secara umum tugas hukum yaitu dapat memelihara kebaikan dan mencegah suatu kejahatan yang terjadi. Dengan kata lain, dapat memelihara kegunaan atau manfaat. Sehingga keberadaan hukum diperlukan untuk menjaga agar tidak terjadinya konflik atau bentrokan dari kepentingan individu masing-masing dalam meraih suatu kebahagiaan yang diinginkan. Untuk itu, diperlukan batasan-batasan yang perlu diwujudkan dalam hukum itu sendiri. Apabila tidak, maka dapat menyebabkan homo homini lupus yang berarti manusia menjadi serigala bagi manusia lain. Oleh sebab itu, ajaran penulis Betham dikenal sebagai utilitarianisme yang individual. Adapun

15 Poernomo, Sri Lestari. "Standar Kontrak Dalam Perspektif Hukum Perlindungan Konsumen." Jurnal Penelitian Hukum De Jure 19, no. 1 (2019): 109-120.

${ }^{16}$ Haris, Abd. ETIKA HAMKA; Konstruksi Etik Berbasis Rasional-Religius. LKIS PELANGI AKSARA, (2010), 23-24.

17 Djakfar, H. Muhammad, and M. Ag SH. Etika bisnis: menangkap spirit ajaran langit dan pesan moral ajaran bumi. Penebar PLUS+, (2012), 10-11 
penulis lain yaitu John Stuart Mill yang dipengaruhi lebih banyak oleh pertimbangan psikologis. Ia mengatakan bahwa kebahagiaan merupakan suatu tujuan yang ingin dicapai manusia itu sendiri. Manusia akan berusaha memperoleh dan melakukan berbagai cara untuk bahagia melalui hal-hal yang membangkitnya nafsu manusia itu sendiri. Pada sisi lain, Mill menolak pandangan Kant yang mengajarkan bahwa individu harus bersimpati dalam kepentingan umum. Kemudian Mill menganalisis hubungan antara kegunaan dan keadilan. Yang pada umumnya, perasaan individu akan keadilan, dapat membuat individu tersebut menyesal dan ingin membalas setiap perbuatan yang tidak menyenangkan bagi individu tersebut. ${ }^{18}$

Pendapat lain dari penulis Rudolf Von Jhering menggabungkan atanta utilitarianisme individual dan utilitarianisme sosial, oleh sebab itu Jhering biasa dikenal dengan pandangan utilitarianisme yang bersifat sosial. Sehingga merupakan gabungan antara teori yang dilontarkan oleh Bentham, Mill dan positivism hukum yang dicetuskan John Austin. Bentham mencetuskan salah satu prinsip dari teori utilitarianisme ke dalam lingkaran hukum, yaitu manusia akan mendapatkan kebahagiaan sebesar-besarnya dan mengurangi penderitaan ${ }^{19}$

Dengan demikian, tujuan hukum menurut Jhering yaitu untuk melindungi kepentingan-kepentingan seseorang. Jhering dan Bentham mengartikan kepentingan yaitu dengan melukisnya sebagai pencapaian kebahagiaan dan menghindari penderitaan, namun kepentingan individu yang menjadi bagian dari tujuan social dengan menghubungkan tujuan pribadi seseorang dengan kepentingan orang lain. ${ }^{20}$

Dari yang telah dipaparkan diatas maka utilitarianisme memandang bahwa, perilaku atau tindakan yang baik merupakan perilaku yang menimbulkan kebahagiaan yang memiliki kualitas dalam pandangan kebijaksanaan, bukan hanya bahagia yang hedonistic-materialistik-kapitalistik. ${ }^{21}$ Kebahagiaan yang menciptakan rasa damai, menciptakan keharmonisan dalam hidup. Utilitarianisme berusaha memperjuangkan perilaku yang dapat menebarkan banyak kebahagiaan dan mengikis penderitaan dalam kehidupan manusia.

Meskipun berguna dan penting bagi bisnis, teori utilitarisnisme mempunyai kelemahan yang mendasar antara lain: ${ }^{22}$

1. Utilitarianisme mengamsusikan bahwa kemanfaatan atau kebahagiaan, kesenangan ataupun penderitaan dapat diukur. Seperti contohnya akuntan handal dalam hal mengukur transaksi ekonomi yang dalam bentuk uang. Uang yang merupakan standard pengukuran yang sangat seragam, namun tidak ada pengukuran umum untuk mencapai kebahagiaan. Tidak pula kesenangan seseorang setara dengan kesenangan orang lain;

2. Soal distribusi, intensitas kebahagiaan, prinsip utilitarianisme yaitu untuk menimbulkan sebanyak mungkin kemanfaatan dan kebahagiaan yang

${ }^{18}$ Kartanegara, Mulyadhi. "Pemikiran Etika Dan Kebahagiaan."

${ }^{19}$ Helmanida, Helmanida. "Utilitarianisme Dalam Filsafat Hukum." Simbur Cahaya Majalah Ilmiah Fakultas Hukum UNSRI 16, no. 45 (2011): 2551-2562.

20 Septiansyah, Zainal B., and Muhammad Ghalib. "Konsepsi Utilitarianisme dalam Filsafat Hukum dan Implementasinya di Indonesia." Ijtihad 34.1 (2019), 13-14

${ }^{21}$ Ibrahim, Teguh, and Ani Hendriani. "Kajian Reflektif Tentang Etika Guru Dalam Perspektif Ki Hajar Dewantara Berbalut Filsafat Moral Utilitarianisme." NATURALISTIC: Jurnal Kajian Penelitian Pendidikan dan Pembelajaran 1, no. 2 (2017): 135-145.

${ }^{22}$ Weruin, Urbanus Ura. "Teori-Teori Etika Dan Sumbangan Pemikiran Para Filsuf Bagi Etika Bisnis." Jurnal Muara Ilmu Ekonomi dan Bisnis 3, no. 2 (2019): 313-322. 
mendistribusikan kepada sebanyak mungkin masyarakat. Tetapi dalam praktek, utilitarianisme sepi dalam prinsip lain seperti keadilan dan kesetaraan;

3. Masalah pengukuran lainnya adalah tentang ruang lingkup;

4. Dalam teori utilitarianisme tidak memperhatikan motivasi dan hanya mengacu pada konsekuensi. Pada hal dapat saja terjadi bahwa konsekuensinya sama namun motivasinya berbeda. Sehingga utilitarianisme tidak cukup menghasilkan keputusan etis yang komprehensif.

Menurut teori utilitarianisme, suatu tindakan atau perbuatan baru dapat dinilai apabila akibat dan tujuannya sudah dipertimbangkan. Manusia tidak dapat hidup sendiri karena manusia merupakan makhluk sosial. Jika terdapat kebijakan atas nama kepentingan bersama, maka kepentingan bersama lah diutamakan dibandingkan kepentingan pribadi. Sehingga suatu tindakan tersebut lebih mendatangkan kebahagiaan terhadap orang banyak.

Sebenarnya Utilitarianisme Mill merupakan utilitarianisme yang menyatakan bahwa, secara moral manusia wajib untuk menjauhkan ataupun mencegah diri dari hal yang dapat membahayakan diri sendiri. Sehingga seseorang akan melakukan sesuatu tindakan yang lebih memperhatikan kebahagiaan orang banyak agar tidak mendatangkan hal yang membahayakan yang tidak diinginkan. ${ }^{23}$

Kebahagiaan merupakan kesenangan dan kebebasan dari rasa sedih atau sesuatu yang membebaskan sejauh mungkin penderitaan dan didekatkan dengan rasa penuh kebahagiaan. Sehingga kebahagiaan tersebut juga merupakan sesuatu hal yang menjadi tujuan utama yang ingin diinginkan oleh banyak orang. Dalam aspek minimalis dari teori utilitarianisme, yaitu mengizinkan Mill untuk memberikan saran bahwa sebelum melakukan sesuatu tindakan harus dapat menumbuhkan rasa bahagia terhadap banyak orang.

Menurut pemikiran utilitarianisme bahwa memerlukan standar moralitas. Moralitas dalam artian menegaskan suatu aturan yang dapat memimpin seseorang. Hal pokok yang terdapat pada utilitarianisme sebagai teori moral yaitu untuk membedakan suatu perilaku atau perbuatan yang baik maupun yang perbuatan yang buruk dari seseorang dalam melakukan suatu perbuatan. Dalam pandangan, seseorang yang dapat dikatakan baik secara moral, bahwa seseorang tersebut selalu berperilaku dari maksud yang baik. Sehingga dapat dimengerti, bahwa kebahagiaan maupun kesenangan tidaklah diukur secara kuantitatif melainkan diukur secara kualitatif. Kebahagiaan seseorang haruslah lebih tinggi dibandingkan makhluk hidup lainnya selain manusia karena hanya manusia yang memiliki kemampuan untuk berpikir. Adapun standar dari moral suatu kebahagiaan utilitarianisme selain sesuatu yang dianggap baik untuk diri sendiri, haruslah baik bagi kebahagiaan orang lain juga. ${ }^{24}$

Utilitarianisme memiliki salah satu kekuatan yaitu utilitarianisme menggunakan prinsip yang jelas dan rasional, sehingga dengan menggunakan prinsip tersebut, pemegang kekuasaan memiliki pegangan yang kuat dalam membentuk kebijaksanaannya dalam mengatur masyarakat. Kekuatan lainnya yang dimiliki yaitu orientasi utama pada teori ini yaitu pada hasil perbuatannya. Suatu perbuatan yang memiliki akibat yang tidak baik, karena diumpakan mengakibatkan orang lain

\footnotetext{
${ }^{23}$ Ibid.

${ }^{24}$ Septiansyah, Zainal B., and Muhammad Ghalib, loc.it
} 
mengalami musibah yang memiliki peluang besar untuk dianggap secara etis dinilai tidak baik dibandingkan perbuatan yang memiliki akibat baik seperti suka menolong orang lain ketika mengalami kesusahan.

Prinsip dari Teori utilitarianisme dapat dikatakan dijabarkan menjadi tiga kriteria prinsip teori utilitarianisme yaitu sebagai berikut: 25

a. Manfaat: dalam suatu tindakan maupun perbuatan harus dapat memberikan manfaat maupun kegunaan tertentu yang ditimbulkannya

b. Manfaat terbesar: bahwa suatu tindakan atau perbuatan itu menghasilkan manfaat yang terbesar dibandingkan alternative lainnya. Sehingga tanpa dalam melakukan suatu tindakan yang tanpa menimbulkan suatu penderitaan bagi orang lain.

c. Manfaat terbesar bagi banyak orang: bahwa dalam suatu tindakan maupun perbuatan dinilai baik secara moral tidak hanya memberikan manfaat terbesar bagi sedikit orang, melainkan akan mendatangkan manfaat yang terbesar bagi sebanyak mungkin orang.

Sehingga, bertindak dan berbuatlah sebaik mungkin tanpa membuat seseorang itu mengalami penderitaan agar tindakan tersebut dapat mendatangkan keuntungan sebesar mungkin bagi sebanyak mungkin orang.

Adapun tiga nilai sisi positif dari utilitarianisme yaitu prinsip moral yang dinyatakan dalam teori utilitarianisme yang tidak didasarkan aturan yang kaku, sehingga dapat memberikan sisi yang objektif dan rasional. Teori ini sangat bertoleransi terhadap kebebasan setiap pelaku moral dalam berpikir dan bertindak sehingga tidak adanya paksaan orang untuk melakukan sesuatu tindakan yang tidak diketahui alasannya, serta teori ini menonjolkan manfaat dan akibat yang ditimbulkan dari suatu tindakan atau perbuatan bagi banyak orang. Sehingga dapat dikatakan nilai positif dari utilitarianisme terdapat pada sisi rasional dan universalnya. Dalam segi sisi rasional yaitu lebih mengutamakan kepentingan umum dibandingkan kepentingan pribadi setiap individu. Sedangkan sisi universal yaitu semua pelaku bisnis, sekarang ini berlomba-lomba untuk mendamaikan atau memberikan manfaat bagi banyak orang sehingga berbisnis untuk kepentingan pribadi individu dan di saat yang bersamaan dalam mendamaikan masyarakat luas merupakan pekerjaan professional yang sangat mulia bukan hanya membuat seseorang tersebut menjadi sejahtera saja.

Pada suatu perusahaan dalam memusatkan bisnisnya, proses bisnis yang dikelola diupayakan untuk selalu mendatangankan keuntungan dibandingkan kerugian yang dialami. Keuntungan dan kerugian tersebut tidak hanya mengenai finansial, tetapi dalam aspek-aspek moral seperti dalam mempertimbangkan kepentingan dan hak dari konsumen itu sendiri. Dalam dunia bisnis dikenal dengan tanggung jawab sosial perusahaan (corporate social responsibility). Sehingga pemikiran tersebut sejalan dengan konsep dari teori ini, oleh sebab itu setiap perusahaan yang memiliki tanggung jawab dalam meningkatkan taraf hidup masyarakatnya. Dan juga setiap perusahaan yang berjalan dengan baik dipastikan menggunakan sumber daya manusia dan alam dan menghabiskan daya guna sumber daya tersebut.

Dalam pencantuman kontrak standar atau klausula baku dalam UndangUndang Perlindungan Konsumen (UUPK) merupakan hal yang dilarang akan tetapi dalam prakteknya di Indonesia, kontrak standar diberlakukan untuk memudahkan

${ }^{25}$ Fattah, Damanhuri. "Teori keadi lan menurut john rawls." Jurnal Tapis: Jurnal Teropong Aspirasi Politik Islam 9.2 (2013): 30-45. 
kegiatan-kegiatan ekonomi. Misalnya perjanjian kredit di koperasi, bank dan lembaga keuangan lainnya yang bentukan kontraknya telah di draft sama sedemikian rupa, pihak nasabah juga tidak bisa bernegosiasi selain dari jumlah plafon dan bunga, sisanya mengenai ketentuan-ketentuan kredit telah diatur secara baku oleh lembaga keuangan. Selain itu perjanjian waralaba tentunya menerapkan standar kontrak, untuk menyelamatkan sistem dagang dan merek dagang yang diperjualbelikan melalui perjanjian, karena pada dasarnya orang berminat untuk membeli waralaba atau franchise harus mengikuti ketentuan yang diberikan oleh pemilik waralaba, jika tidak maka pemilik waralaba tidak akan memberikan izin menggunakan system dan merek dagangnya. Berdasarkan hal tersebut dapat dilihat perbedaan kedudukan dari para pihak yang salah satunya pasti akan lebih lemah terutama konsumen.

Namun perjanjian-perjanjian seperti waralaba sangat membantu proses pengembangan ekonomi di masyarakat karena memudahkan masyarakat membuka lapangan pekerjaan dan membentuk badan usaha. Ketika Kontrak standar atau Klausula Baku memberikan manfaat bagi para pihak terutama bagi perkembangan hukum ekonomi terutama dalam bidang bisnis maka hal tersebut sesuai dengan teori Utilitarianisme, karena hukum yang dianggap baik yaitu hukum yang memberikan manfaat dan kebahagiaan bagi masyarakat sekitar. Namun apabila kontrak standar ini dianggap tidak memberikan kebahagiaan dan hanya merugikan sebagaimana UU Perlindungan Konsumen maka dari perspektif Utilitarianisme, menganggap kontrak standar tidak sesuai dipergunakan dalam perkembangan hukum ekonomi di Indonesia.

\section{Kesimpulan}

Penerapan kontrak standar dalam perkembangan pembangunan ekonomi dapat dikatakan apabila konsumen telah mencantumkan tanda tangan di atas kontrak standar yang telah dilakukan pelaku usaha kepada konsumen, maka hal tersebut berarti konsumen secara tidak langsung telah menyetujui (take it) klausul-klausul perjanjian yang tercantum dalam kontrak standar tersebut. Sehingga lahirlah hak dan kewajiban pelaku usaha dan konsumen dengan adanya aturan-aturan yang menjadi acuan agar kontrak standar tersebut bersifat saling mengikat satu sama lain. Jika dilihat dari perspektif Utilitarianisme maka pada dasarnya yang harus dilihat adalah suatu kemanfaatan dalam hukum. Ketika Kontrak standar atau Klausula Baku memberikan manfaat bagi para pihak terutama bagi perkembangan hukum ekonomi terutama dalam bidang bisnis maka hal tersebut sesuai dengan aliran Utilitarianisme. Namun apabila kontrak standar ini dianggap tidak memberikan kebahagiaan dan hanya merugikan sebagaimana yang diatur dalam Undang-Undang Perlindungan Konsumen (UUPK) maka, maka dari perspektif aliran tersebut kontrak standar tidak sesuai dipergunakan dalam perkembangan hukum ekonomi.

\section{DAFTAR PUSTAKA}

Buku

Syaifuddin, Muhammad, Hukum Kontrak (Bandung, Mandar Maju, 2012), 56- 57

Hernoko, Agus Yudha, Hukum Perjanjian Asas Proposional Dalam Kontrak Komersial, (Jakarta, Kencana, 2010), 35-36. 


\section{Jurnal}

Djakfar, H. Muhammad, and M. Ag SH. Etika bisnis: menangkap spirit ajaran langit dan pesan moral ajaran bumi. Penebar PLUS+, (2012), 10-11

Fattah, Damanhuri. "Teori keadilan menurut john rawls." Jurnal Tapis: Jurnal Teropong Aspirasi Politik Islam 9.2 (2013): 30-45.

Fuad, Fokky. "Hukum, Demokrasi dan Pembangunan Ekonomi." Lex Jurnalica 5, no. 1 (2007): 17959.

Haris, Abd. ETIKA HAMKA; Konstruksi Etik Berbasis Rasional-Religius. LKIS PELANGI AKSARA, (2010), 23-24.

Helmanida, Helmanida. "Utilitarianisme Dalam Filsafat Hukum." Simbur Cahaya Majalah Ilmiah Fakultas Hukum UNSRI 16, no. 45 (2011): 2551-2562.

Hendrawati, Dewi. "Penerapan Asas Kebebasan Berkontrak dalam PembuatanPerjanjian Baku (Studi Normatif pada Perjanjian Pembiayaan Konsumen)." Masalah-Masalah Hukum 40, no. 4 (2011): 411-418.

Ibrahim, Teguh, and Ani Hendriani. "Kajian Reflektif Tentang Etika Guru Dalam Perspektif Ki Hajar Dewantara Berbalut Filsafat Moral Utilitarianisme" NATURALISTIC: Jurnal Kajian Penelitian Pendidikan dan Pembelajaran 1, no. 2 (2017): 135-145.

Jamilah, Lina. "Asas Kebebasan Berkontrak Dalam Perjanjian Standar Baku." Syiar Hukum 14, No. 1 (2012): 26-36.

Junaidy, Abdul Basith. "Memahami Maslahah Melalui Filsafat Manfaat: Utilitarianisme." Penelitian Individu (2013),12-13 Kartanegara, Mulyadhi. "Pemikiran Etika Dan Kebahagiaan."

Khairandy, Ridwan. "Landasan Filosofis kekuatan mengikatnya kontrak." Jurnal Hukum IUS QUIA IUSTUM 18 (2011): 36-55.

Mariam Badrulzaman, Aneka Hukum Bisnis, (Bandung, PT Alumni, 2005), 18-19

Munir Fuady, Dr SH. Doktrin-doktrin modern dalam corporate law E eksistensinya dalam hukum Indonesia. Citra Aditya Bakti, (2014), 22-23

Muskibah, Muskibah, and Lili Naili Hidayah. "Penerapan Prinsip Kebebasan Berkontrak Dalam Kontrak Standar Pengadaan Barang Dan Jasa Pemerintah Di Indonesia." Refleksi Hukum: Jurnal Ilmu Hukum 4, no. 2 (2020): 175-194.

Panggabean, R. M. "Keabsahan Perjanjian dengan Klausul Baku." Jurnal Hukum Ius Quia Iustum 17.4 (2010): 651-667.

Poernomo, Sri Lestari. "Standar Kontrak Dalam Perspektif Hukum Perlindungan Konsumen." Jurnal Penelitian Hukum De Jure 19, no. 1 (2019): 109-120.

Radjagukguk, Erman, Peranan Hukum Dalam Pembangunan Pada Era Globalisasi, Jurnal Magister Hukum 6, No. 2 (2018): 114.

Septiansyah, Zainal B., and Muhammad Ghalib. "Konsepsi Utilitarianisme dalam Filsafat Hukum dan Implementasinya di Indonesia." Ijtihad 34, no. 1 (2019).

Weruin, Urbanus Ura. "Teori-Teori Etika dan Sumbangan Pemikiran Para Filsuf Bagi Etika Bisnis." Jurnal Muara Ilmu Ekonomi dan Bisnis 3, no. 2 (2019): 313-322.

Zaini, Zulfi Diane. "Perspektif Hukum Sebagai Landasan Pembangunan Ekonomi Di Indonesia (Sebuah Pendekatan Filsafat)." Jurnal Hukum 28, no. 2 (2020): 929-957.

\section{$\underline{\text { Tesis }}$}

Ardana, I Nyoman, Kewenangan Pejabat Pembuat Akta Tanah Dalam Pembebanan Hak Tanggungan, Tesis Universitas Mahendradatta, Denpasar (2013), 23. 


\section{Peraturan Perundang-Undangan}

Kitab Undang-Undang Hukum Perdata (Burgerlijk Wetboek)

Undang-Undang Republik Indonesia Nomor 8 Tahun 1999 Tentang Perlindungan Konsumen (Lembaran Negara Republik Indonesia Tahun 1999 Nomor 42, Tambahan Lembaran Negara Republik Indonesia Nomor 3821) 